\title{
Population dynamics and trophic coupling in pelagic microorganisms in eutrophic coastal waters
}

\author{
Per Andersen \& Helene M. Sørensen* \\ Department of Ecology and Genetics, University of Aarhus, Ny Munkegade, 8000 Aarhus C, Denmark
}

\begin{abstract}
Pelagic bacteria, heterotrophic and autotrophic nanoflagellates, and ciliates were quantified in the marine shallow-water sound, Limfjorden, Denmark, from March to November 1983. During summer the populations showed pronounced oscillations with time scales of days or weeks. Concentrations of bacteria, heterotrophic nanoflagellates and ciliates ranged from 0.5 to $15.2 \times 10^{6} \mathrm{ml}^{-1}$ (mean: 6.3), 0.2 to $15.2 \times 10^{3} \mathrm{ml}^{-1}$ (mean: 2.0 ), and 1.4 to $162.0 \mathrm{ml}^{-1}$ (mean: 17.1), respectively. Population sizes of bacteria and heterotrophic nanoflagellates were coupled, as were populations of total nanoplankton and ciliates; in contrast there was no direct coupling between bacteria and ciliates. It is estimated that heterotrophic nanoflagellates on average cleared $45 \%$ (range: 5 to $365 \%$ ) of the watercolumn for bacteria per day during summer. Ciliates on average cleared $93 \%$ (range: 4 to $352 \%$ ) of the water-column for nanoplankton per day.
\end{abstract}

\section{INTRODUCTION}

Pelagic microorganisms have received increasing attention in recent years. Improved methodology has shown that heterotrophic and autotrophic picoplankton (heterotrophic bacteria, cyanobacteria and the smallest eucaryotic autotrophs), heterotrophic and autotrophic nanoflagellates and heterotrophic microplankton (ciliates and dinoflagellates) play a significant quantitative role in marine ecosystems (e.g. Azam et al. 1983, Ducklow 1983, Williams 1984, Fenchel 1986a).

Based on quantitative in situ observations and especially laboratory experiments, it is now believed that heterotrophic nanoflagellates are the most important grazers on the productive picoplankton while most ciliates depend entirely on nanoplankton organisms for food (Sorokin 1977, 1981, Heinbokel 1978a, b, Haas \& Webb 1979, Beers et al. 1980, Fenchel 1980, 1982a to d, 1984, 1986a, b, Davis \& Sieburth 1982, 1984, Johnson et al. 1982, Ducklow 1983, Laake et al. 1983, Sherr et al. 1984, Williams 1984, Andersen \& Fenchel 1985, Davis et al. 1985, Verity 1985, 1986a, b).

The aim of the present investigation is to describe

\footnotetext{
- Present address: Teknik \& Miliøforvaltningen, I. C. Christensens Alle 1, 6950 Ringkjøbing, Denmark

the in situ population dynamics of the different functional groups of pelagic microorganisms. The intensive sampling program was designed to permit a high temporal resolution of sequential population developments and to gather evidence for trophic couplings between the groups investigated. Furthermore, an attempt is made to estimate in situ clearance and growth rates and to compare these values with those obtained from laboratory cultures.

\section{MATERIALS AND METHODS}

Investigation area and sampling. Sampling took place at one station at 1 and $2 \mathrm{~m}$ depth (max. depth at the station ca $5 \mathrm{~m}$ ), in the central part of the Limfjord, off the Ronbjerg Marine Biological Station. The Limfjord is a $150 \mathrm{~km}$ long sound with a mean depth of 7 to $8 \mathrm{~m}$, connecting the North Sea to the Kattegat (Fig. 1). The mean turnover time of water in the sound is 0.75 $\mathrm{yr}^{-1}$ (Anon. 1976). Temperatures ranged from 3 to $22^{\circ} \mathrm{C}$ during the sampling period; salinity was around $25 \%$ (range: 24.4 to $27.7 \%$ ). For the period April to August 1983 phytoplankton biomass, measured as chlorophyll, was between 1 and $12 \mu \mathrm{g} \mathrm{chl}{ }^{-1}$ (the Secchi depth was within the range 1 to $4 \mathrm{~m}$ ), and C-14 primary production was $130 \mathrm{~g} \mathrm{~m}^{-2}$ (Limfjordskomiteen, pers. comm.). 


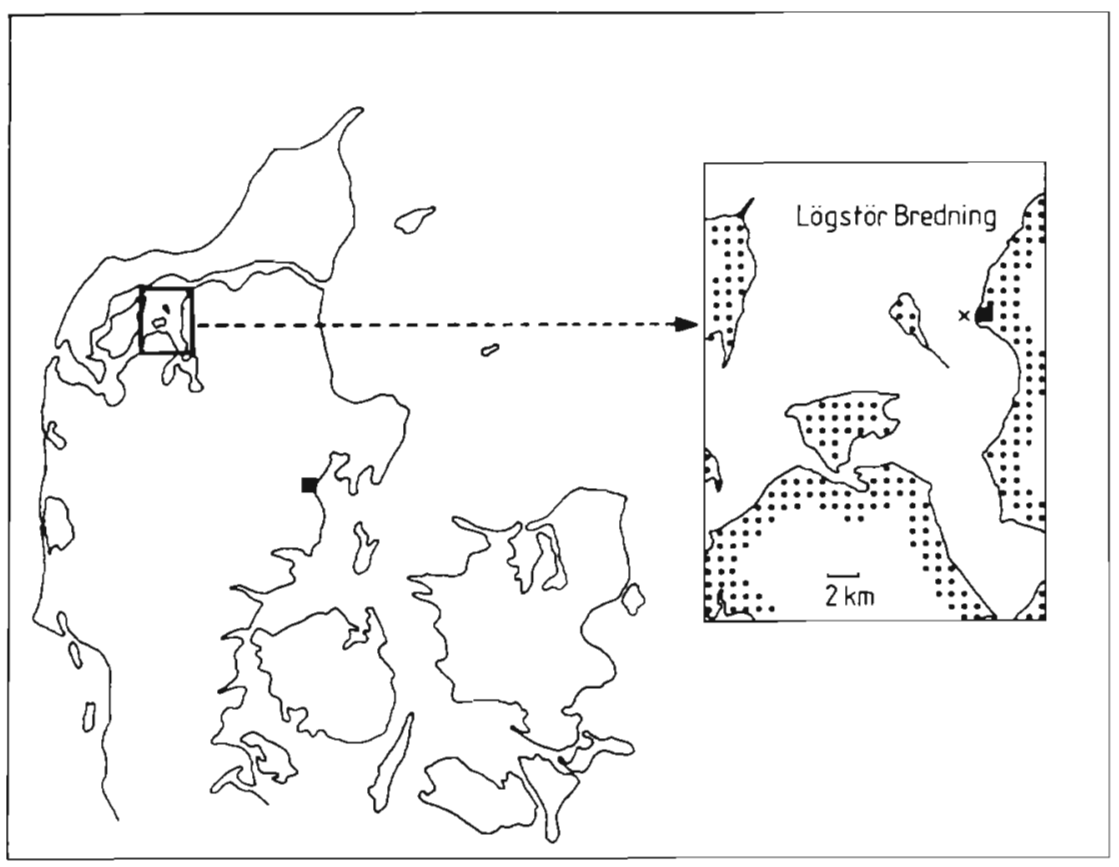

Fig. 1. Map of Denmark showing the Limfjord and the sampling area in detail. $\mathrm{x}$ : sampling station

Primary production is apparently nitrogen-limited during summer. Sampling began in March and continued until November 1983. Frequency of sampling was 3 or 4 times $\mathrm{mo}^{-1}$ during spring and autumn/winter. Between May and July we sampled approximately every second day. Other areas of the Limfjord were occasionally sampled to obtain data for comparison with the main station. Samples were collected using a 0.751 Hydrobios water sampler equipped with a thermometer.

Quantification of microorganisms. Formaldehyde was added to known volumes of water (final conc. $1.5 \%$ ) immediately after collection and the fixed samples were kept in the dark at $5^{\circ} \mathrm{C}$ until counting (within $24 \mathrm{~h}$ ). Organisms were quantified using epifluorescence microscopy with acridine orange as a fluorochrome (Hobbie et al. 1977). Bacteria and nanoplankton were concentrated on $0.2 \mu \mathrm{m}$ Nuclepore polycarbonate filters. Filters were mounted in paraffin oil. B a cteria were counted from samples of 2 to $5 \mathrm{ml}$, depending on the expected concentrations. At least 200 bacteria (per filter) were counted (SD $<7 \%$ ). $\mathrm{N}$ anoplankton cells were counted from similar samples $(5$ to $10 \mathrm{ml}$ ), but with a final concentration of acridine orange of only $2.4 \mathrm{ppm}$. This dilute concentration allows for an improved resolution of the outline and basic morphology of the cells including chloroplasts containing chlorophyll or phycoerythrin with red and gold autofluorescence respectively. Furthermore, the nucleus, ingested bacteria and picophytoplankton in food vacuoles, captured bacteria on the pseudopodial collar of choanoflagellates, flagellae, body scales of some chrysomonads and thecal plates of dinoflagellates can also be distinguished. The mounted preparations can be kept in a freezer for several weeks with no significant loss of fluorescence. Usually more than 40 flagellates per filter were counted (SD $<16 \%)$. Cili a te s were quantified in a similar way using 10 to $50 \mathrm{ml}$ samples depending on expected concentrations and concentrated on $5 \mu \mathrm{m}$ membrane filters. The entire surface of the filters were counted at $100 \times$ or $400 \times$ magnification depending on the size of the ciliates to be examined.

Identification of species. The species composition of the nanoplankton and of the ciliate fauna, as revealed by epifluorescence microscopy was checked on live or fixed preparations from freshly collected water samples concentrated with plankton gauze (mesh size $35 \mu \mathrm{m}$ ), reversed filtration (mesh size $10 \mu \mathrm{m}$ ), centrifugation, sedimentation (Utermöhl technique), or bacterial enrichment cultures based on the addition of boiled wheat grains to water samples. The preparations were examined by phase contrast microscopy or transmission electron microscopy on whole mounts on formvar/carbon coated grids (Fenchel 1982a, Moestrup \& Thomsen 1982). For ciliates, Lugol's fixative gave good preparations, while the flagellates were fixed either in formaldehyde (final conc. $1.5 \%$ ), or $\mathrm{OsO}_{4}$ (applied as vapor or as $1 \%$ solution).

Biomass estimation. Biovolume was estimated from measurements of linear dimensions and assuming simple geometric shapes of the organisms. The following conversion factors from wet-weight to carbon were used: bacteria, $8.6 \%$ (Ferguson \& Rublee 1976); 
diatoms, $10 \%$ (Strathmann 1967); other phytoplankton and heterotrophic flagellates, $13 \%$ (Strathmann 1967). At least 50 cells were measured for each biovolume estimate.

\section{RESULTS}

The most common species found during the investigation period are listed in Table 1. Quantitative popu- lation data presented as mean concentrations at the 2 sampling depths are provided in Fig. 2 \& 3. During the investigation period concentrations of bacteria, heterotrophic nanoflagellates and ciliates ranged from 0.5 to $15.2 \times 10^{6} \mathrm{ml}^{-1}$ (mean: 6.3), 0.2 to $15.2 \times 10^{3} \mathrm{ml}^{-1}$ (mean: 2.0 ), and 1.4 to $162.0 \mathrm{ml}^{-1}$ (mean: 17.1 ), respectively. Spatial heterogeneity in the distribution of the microorganisms was low (generally of the same size as sampling variance) as compared to temporal changes. The mean differences between 1 and $2 \mathrm{~m}$ depth were

Table 1. Organisms of quantitative importance in the Limfjord during the period Mar to Nov 1983

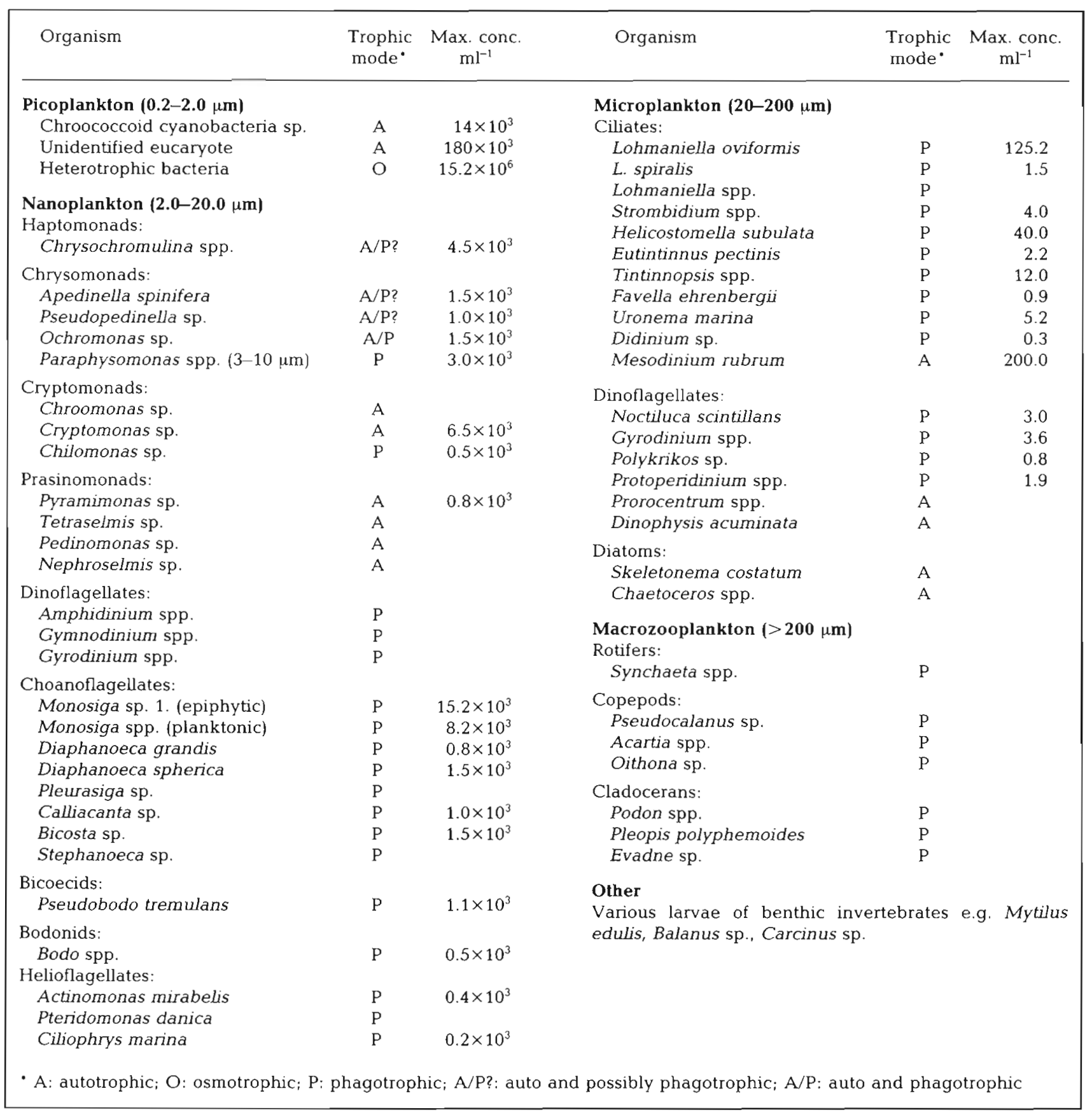



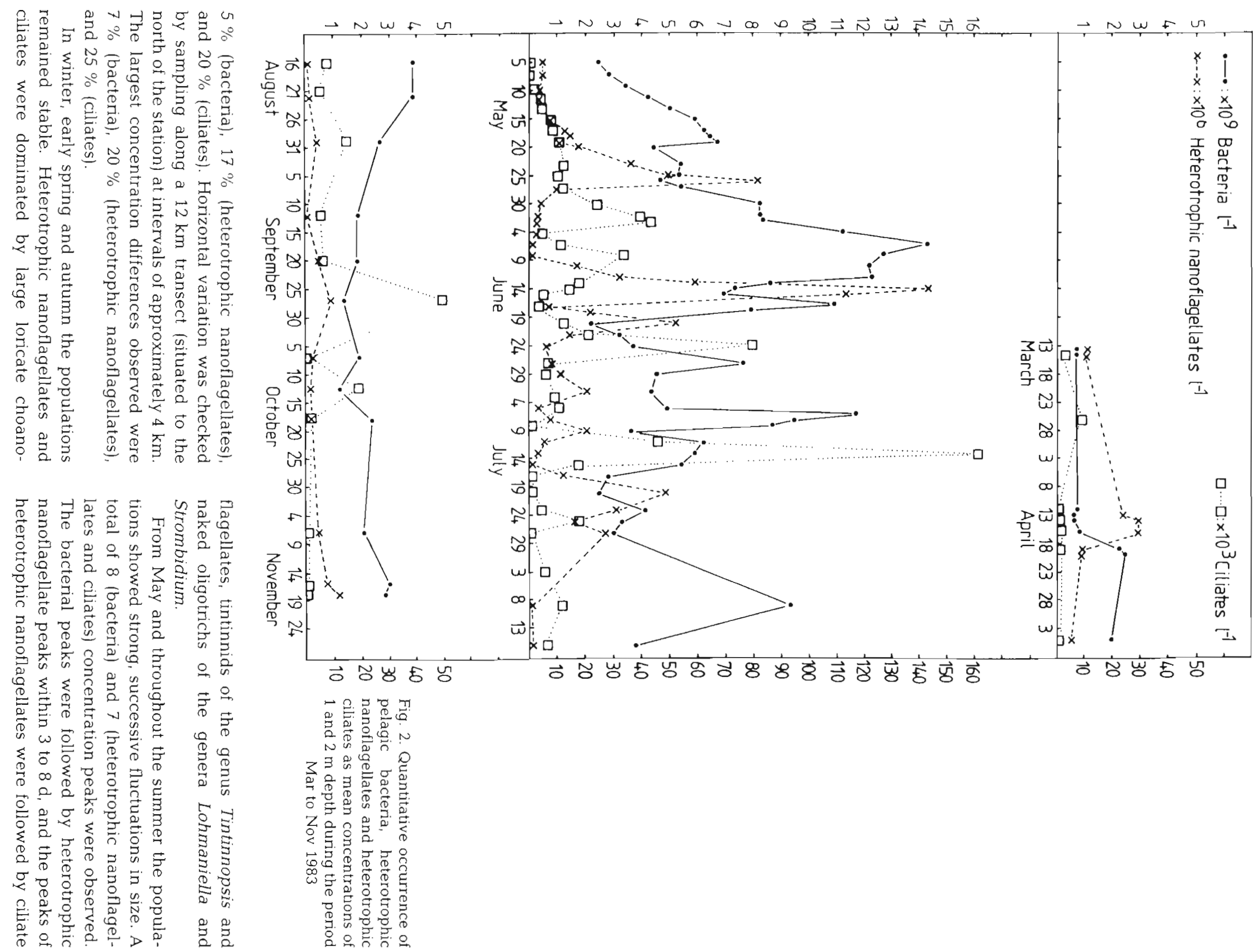
Fig. 3. Quantitative occurrence of total nanoplankton, naked heterotrophic ciliates and tintinnids as mean concentrations of 1 and $2 \mathrm{~m}$ depth during the period Mar to Nov 1983

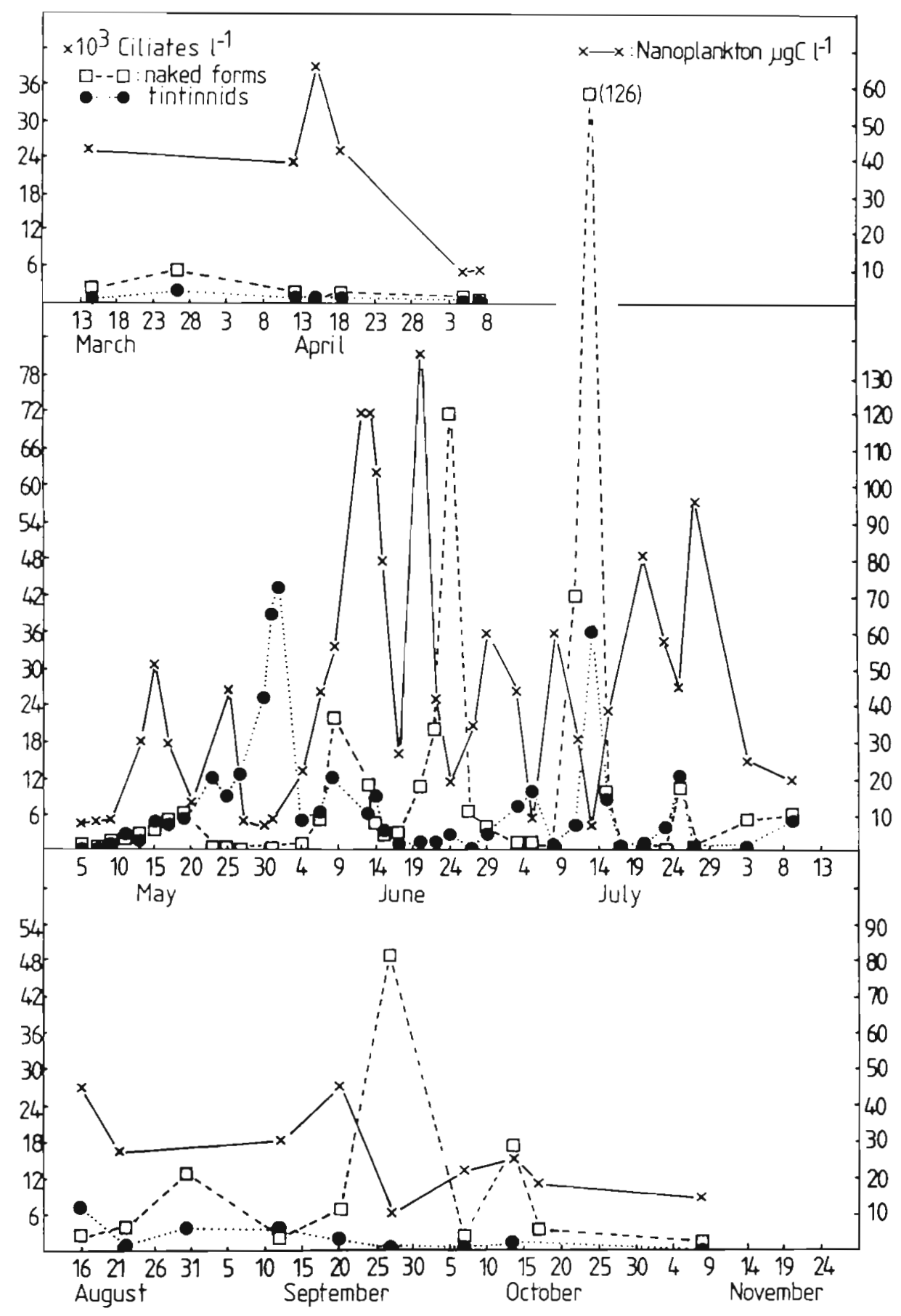

peaks within 4 to $6 \mathrm{~d}$. The successive periods of the oscillations were of similar length for the 3 trophic groups (range 7 to 23 d) (Fig. $4 \& 5$ ). The populations of heterotrophic nanoflagellates were dominated by naked choanoflagellates (Monosiga), chrysomonads (Paraphysomonas) and the non-loricate bicoesid Pseudobodo tremulans. The ciliate populations were dominated by the small naked oligotrich Lohmaniella oviformis (15 to $30 \mu \mathrm{m})$ and tintinnids Helicostomella subulata and Eutintinnus pectinis. The small scuticociliate Uronema spp. (20 to $40 \mu \mathrm{m})$ occurred at low concentrations $\left(<0.01 \mathrm{ml}^{-1}\right.$ ) throughout the period with a maximum concentration on June 24 of $5.2 \mathrm{ml}^{-1}$.

Throughout the entire period bacterial populations were dominated by freely suspended forms (>95\%) whereas detrital particles (in general found at concentrations $<10 \mathrm{ml}^{-1}$ ) harboured only few attached bacteria. 


\section{DISCUSSION}

The dynamic population fluctuations which started in May were apparently triggered by a combination of increasing temperature, a change in the primary production, and a decrease in the numbers of rotifers and benthic invertebrate larval plankton (unpubl. data), so that the pelagic system was dominated by bacteria, nanophytoplankton, Protozoa and occasionally diatoms.

The trophic couplings between bacteria and heterotrophic nanoflagellates and between nanoplankton and ciliates, respectively, were especially clear throughout this period, and can be visualized by following the population developments of the different trophic groups (Fig. 2). Starting on May 5, bacterial numbers increased until May 19 when the population size peaked at $6.8 \times 10^{6} \mathrm{ml}^{-1}$. The subsequent decline in numbers was due to grazing by the non-loricate choanoflagellate Monosiga sp., the numbers of which increased during the same period until a peak concentration of $8.2 \times 10^{3} \mathrm{ml}^{-1}$ was reached ca $1 \mathrm{wk}$ after the bacterial peak. From June 25 to July 6 heterotrophic

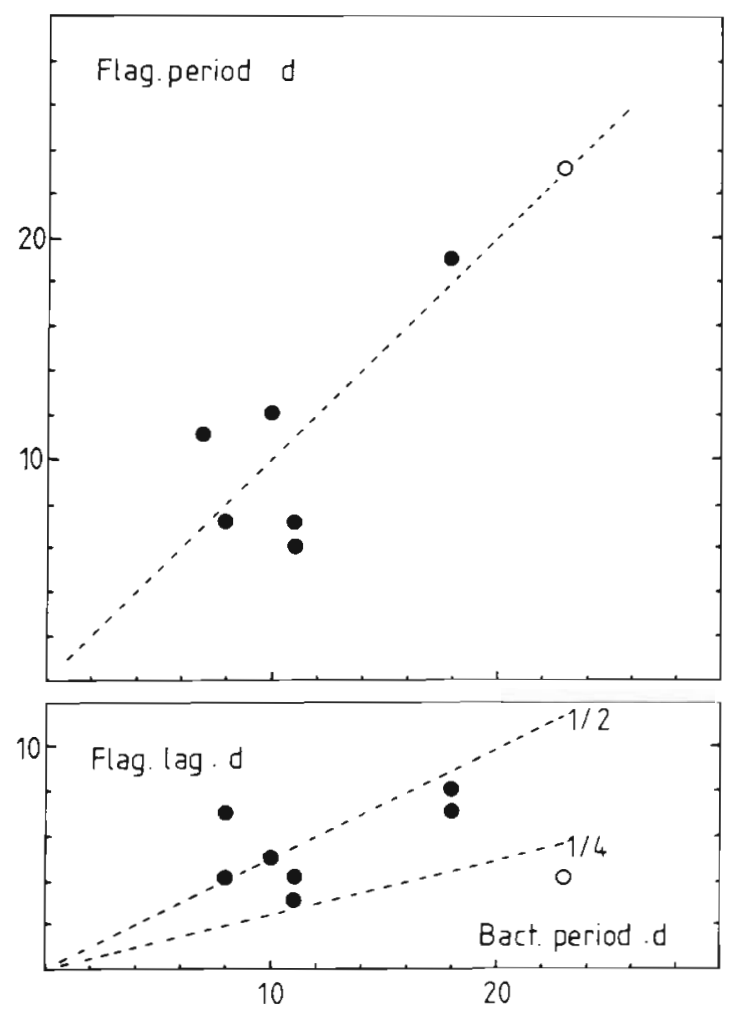

Fig. 4. Upper panel: periods of heterotrophic nanoflagellate oscillations versus corresponding bacterial periods. Lower panel: lag of heterotrophic nanoflagellate peaks versus corresponding bacterial periods. Open symbols indicate data from Fenchel (1982d) nanoflagellates were grazed down to a density of $0.2 \times$ $10^{3} \mathrm{ml}^{-1}$ by the growing ciliate populations (in particular the tintinnid Helicostomella subulata and the naked oligotrich Lohmaniella oviformis). As a direct consequence of this, grazing pressure on bacteria decreased and these continued to grow until they reached their second peak concentration of $15.2 \times 10^{6}$ $\mathrm{ml}^{-1}$ on June 6 . The bacterial population remained at this level until June 9, where an exceptional inflow of water from another part of the fjord complex occurred as a result of a storm, and served as an inoculum of epiphytic choanoflagellates of the genus Monosiga attached to the diatom Skeletonema costatum. Apparently as an effect of their epiphytic mode, the choanoflagellates were not grazed efficiently by the ciliate populations present. Due to this and to the high bacterial concentrations, Monosiga spp. showed a rapid increase in numbers during the following days to reach a maximum concentration of $15.2 \times 10^{3} \mathrm{ml}^{-1}$. This was the highest density of heterotrophic nanoflagellates encountered during the investigation period. During the same period the bacterial population was grazed down to $7.0 \times 10^{6} \mathrm{ml}^{-1}$ on June 15 . Over the following

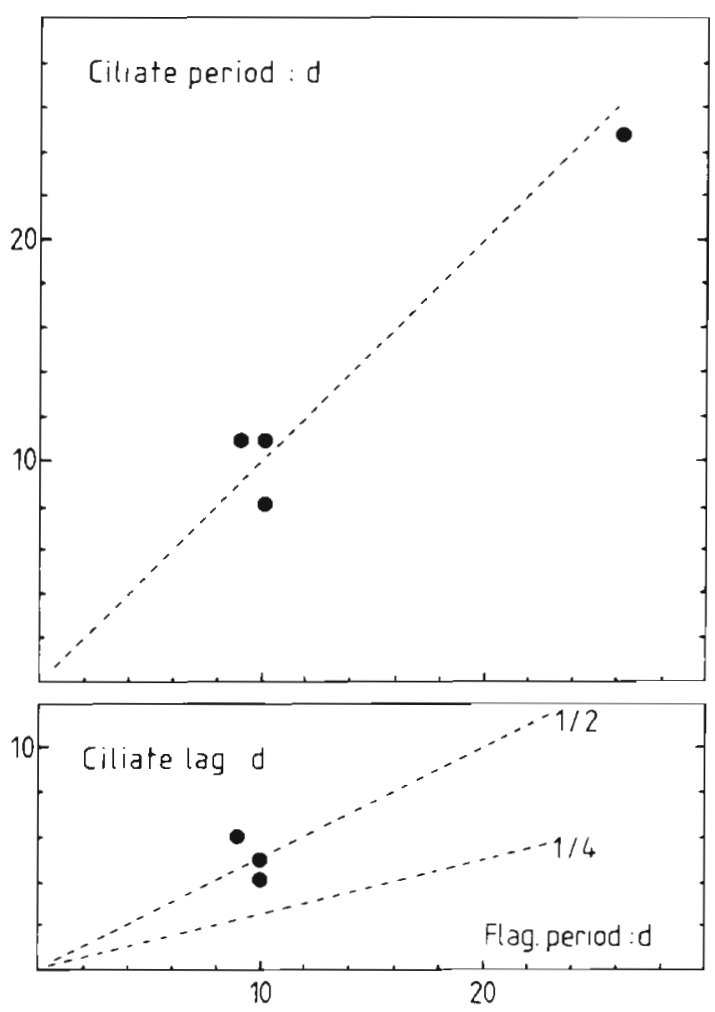

Fig. 5. Upper panel: periods of the ciliate oscillations versus the corresponding nanoplankton periods. Lower panel: lag of the ciliate peaks versus the corresponding nanoplankton periods 
days $S$. costatum disappeared (probably as a result of sedimentation, since the Secchi depth increased from 2 to $4 \mathrm{~m}$ ) and with it the population of the episymbiotic Monosiga spp. and the bacterial population reached its third concentration peak $\left(11.0 \times 10^{6} \mathrm{ml}^{-1}\right)$ on June 17 . During the following period bacterial numbers decreased again due to grazing by the increasing population of heterotrophic nanoflagellates, now dominated by a free-swimming form of Monosiga spp. Eventually this population of flagellates was grazed down by an increasing population of the naked oligotrich Lohmaniella oviformis. As a result of this, the bacterial population increased again. This set of events was repeated again altogether 4 times up to the beginning of August.

Although ciliate concentrations were extremely high compared to estimates from other coastal waters (typically $<1$ to $10 \mathrm{ml}^{-1}$, see Beers \& Stewart 1969, Heinbokel \& Beers 1979, Capriulo \& Carpenter 1983) their impact on the bacterial population developments were negligible as compared to the grazing impact from the heterotrophic nanoflagellates.

The importance of ciliate grazing on the heterotrophic nanoflagellates is reflected by the coupling between the total nanoplankton and ciliate populations, as seen in Fig. 3. The period between June 9 and 15 constitutes an exception. During this period the autotrophic 'nanoplankton' was entirely dominated by a small ( 1 to $2 \mu \mathrm{m})$, coccoid alga, which appeared to be grazed inefficiently by the ciliates. However, its numbers declined rapidly when the choanoflagellates bloomed at the end of the period suggesting that they grazed the algae efficiently.

The cycle periods of bacteria and heterotrophic nanoflagellates were longest at the beginning of the summer. The bacterial population periods were equal in length to those of the heterotrophic nanoflagellates (Fig. 4). The peak size of flagellate populations lagged 3 to $8 \mathrm{~d}$ behind that of the bacteria, viz. $1 / 4$ to $1 / 2$ of the cycle period. This is in general agreement with theoretical models of prey-predator systems (e.g. Christiansen \& Fenchel 1977). The same approach can be used to analyze the relation between the ciliate and nanoplankton populations (Fig. 5). Cycle periods were 8 to $11 \mathrm{~d}$ and the measured ciliate peaks lagged approximately $1 / 2$ period behind the corresponding measured nanoplankton peaks. The population data from June 8 to 18 were not included in the analysis because of the strong influence on the nanoplankton and ciliate populations of the inflow of water, and the apparent settling out of the nanoplankton population. This analysis suggests a tight trophic coupling between the nanoplankton and ciliate populations. This interpretation is furthermore supported qualitatively by frequent observations of nanoplankton-sized partic- les in ciliate food vacuoles. The data suggest that ciliate populations are controlled mainly by the availability of suitable food (the lower threshold limit for tintinnids is about 10 to $20 \mu \mathrm{g} \mathrm{Cl}^{-1}$; Heinbokel 1978a, Verity 1985), and occasionally by grazing from the mesozooplankton, e.g. the heterotrophic dinoflagellate Noctiluca scintillans which occurred in concentrations of $3 \mathrm{ml}^{-1}$ during the period July 18 to 24 , and which was observed with tintinnids in the food vacuoles. Prey-predator interactions among the ciliates themselves, e.g. between Lohmaniella oviformis and the larger tintinnids, might also be responsible for the decline of the ciliate populations.

Fenchel (1982d) observed less pronounced, but comparable, oscillations in bacterial and heterotrophic nanoflagellate populations and showed that the population developments could be simulated using a simple prey-predator model fitted with bioenergetic and growth parameters for the flagellate population obtained from laboratory experiments.

The maximum in situ growth rates (net growth rates) were estimated from linear regressions of logarithmically transformed data using the formula:

$$
\mu=(\ln \mathrm{X}[\mathrm{t}]-\ln \mathrm{X} / \mathrm{O}]) / \mathrm{t}
$$

where $\mu=$ growth rate $\left(\mathrm{d}^{-1}\right) ; \mathrm{X}(\mathrm{t})$ and $\mathrm{X}(\mathrm{O})=$ concentrations of the organisms at the end and beginning of the time interval $t(d)$. These were $0.85 \mathrm{~d}^{-1}$ (bacteria); $0.65 \mathrm{~d}^{-1}$ (heterotrophic nanoflagellates); $1.93 \mathrm{~d}^{-1}$ (Lohmaniella oviformis) and $1.44 \mathrm{~d}^{-1}$ (Helicostomella subulata).

The maximum growth rate estimate for the bacteria is close to what is to be expected for eutrophic coastal waters (see e.g. Ducklow 1983). In the Limfjord, bacterial growth rates have been estimated, using the tritiated thymidine incorporation method (Fuhrman \& Azam 1982), to be within the range of 0.2 to $1.5 \mathrm{~d}^{-1}$ (Riemann et al. 1984, Andersen unpubl. results).

The maximum growth rate estimate of the heterotrophic nanoflagellates are comparable to estimates for mixed populations in laboratory mesocosms (Andersen \& Fenchel 1985) and for pure cultures of comparable species (e.g. Monosiga sp. and Paraphysomonas vestita) (Fenchel 1982b).

The maximum growth rate estimates for the ciliates are comparable to the values of $3.0 \mathrm{~d}^{-1}$ (Lohmaniella oviformis) and $1.2 \mathrm{~d}^{-1}$ (Helicostonella subulata) reported by Smetacek (1981) and Heinbokel (1978a), respectively.

The growth rate of the heterotrophic nanoflagellates is proportional to their ingestion rate of bacteria expressed as:

$$
\mu_{\text {lag. }}=\mathrm{I} \times \mathrm{Y}
$$

where $\mu_{\text {flag. }}=$ growth rate of the flagellates; $\mathrm{I}=$ inges- 
tion rate $(\mathrm{I}=\mathrm{F} \times \mathrm{X}$; where $\mathrm{F}=$ flagellate clearance and $\mathrm{X}=$ bacterial concentration, and $\mathrm{Y}=$ gross growth efficiency of the flagellates). Using the assumptions that the heterotrophic nanoflagellates (average volume $34 \mathrm{\mu m}^{3}$ ) only graze on the bacteria (average volume $0.09 \mu \mathrm{m}^{3}$ ), and that their gross growth efficiency is $30 \%$ (vol/vol) (Fenchel 1982b, Andersen unpubl. results), it can be calculated that the flagellates Monosiga spp. must have cleared between 0.14 and $0.19 \times 10^{-5} \mathrm{ml} \mathrm{h}^{-1}$ to obtain the growth rates of 0.19 and $0.26 \mathrm{~d}^{-1}$ respectively estimated during the period 10 to 25 May (Table 2). For the same period, their clearance was estimated using the population dynamics approach of Andersen \& Fenchel (1985) to be $0.33 \times 10^{-5} \mathrm{ml} \mathrm{h}^{-1}$ (Fig. 6). These estimates are close to values obtained in the laboratory using pure cultures (Fenchel 1982b) or mixed natural populations (Andersen \& Fenchel 1985).

Using the population dynamics approach the clearance of the tintinnid Helicostomella subulata, which entirely dominated the ciliate population during the period 24 to 30 May, was estimated on May 25 to be ca $2 \mu \mathrm{l} \mathrm{h}{ }^{-1}$, a result in reasonable agreement with the values from Heinbokel (1978a) at a similar nanoplankton biomass $\left(50 \mu \mathrm{g} \mathrm{Cl}^{-1}\right)$. These results show that the above interpretation of the population fluctions as prey-predator oscillations is consistent with laboratory data on growth and feeding rates.

During summer, the approximate ratios between the maximum and minimum population sizes $\left(\mathrm{P}_{\max } / \mathrm{P}_{\min }\right)$ was 8 for the bacteria, 75 for the heterotrophic nanoflagellates and 115 for the ciliates. These values clearly reflect the amplitudes of the population oscillations

For simple one prey-one predator systems, the ratio $\mathrm{P}_{\max } / \mathrm{P}_{\min }$ depends on the ratio between the carrying capacity, $K$, and the mean concentration of the prey, $\mathrm{x}^{*}$, and is approximately given by the expression:

$$
\mathrm{P}_{\max } / \mathrm{P}_{\min }=\exp \left(\mathrm{c}\left[\mathrm{K} / \mathrm{x}^{\cdot}\right]^{2}\right)
$$

where $\mathrm{c}=\mathrm{a}$ constant of the order of unity (May 1973, Fenchel 1986a). The equation predicts that the amplitude of the prey-predator oscillations increases with the carrying capacity of the prey. The carrying capacities of the pelagic bacteria and nanoplankton

Table 2. Heterotrophic nanoflagellate clearance estimates from in situ growth rates

\begin{tabular}{|cccccc|}
\hline Date & $\begin{array}{c}\text { Temp. } \\
{ }^{\circ} \mathrm{C}\end{array}$ & $\begin{array}{l}\text { Bact. } \\
\text { conc. } \\
\times 10^{6} \mathrm{ml}^{-1}\end{array}$ & $\begin{array}{c}\boldsymbol{t h}_{\text {nas }} \\
\mathrm{h}^{-1}\end{array}$ & $\begin{array}{c}\mathrm{I} \\
\text { Bact. } \\
\mathrm{h}^{-1}\end{array}$ & $\begin{array}{c}\mathrm{F} \\
10^{-5} \\
\mathrm{ml} \mathrm{h}^{-1}\end{array}$ \\
\hline $11-17$ May & 10 & 5.0 & 0.008 & 7 & 0.14 \\
$19-26$ May & 12 & 5.2 & 0.011 & 10 & 0.19 \\
\hline
\end{tabular}

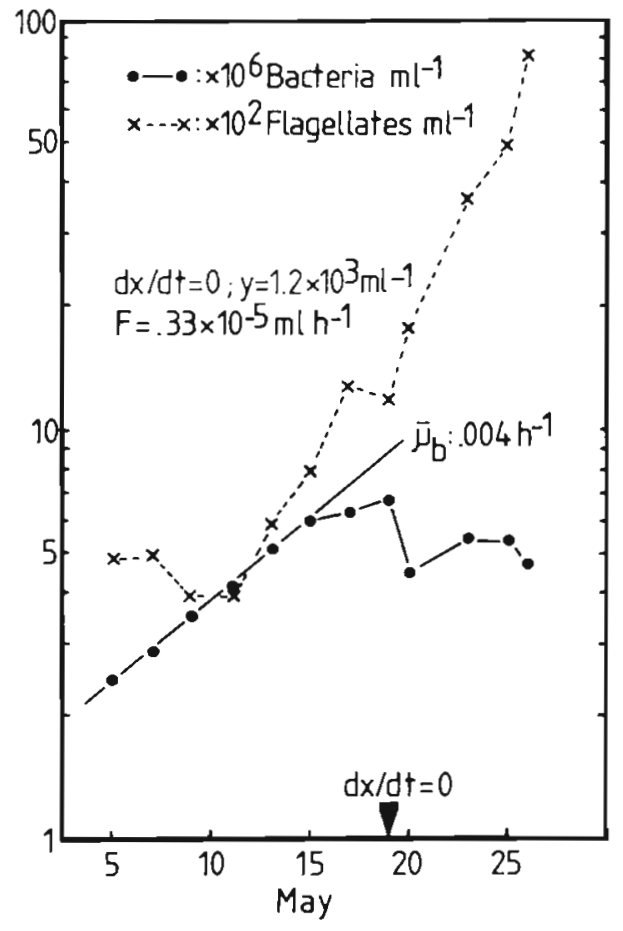

Fig. 6. Population developments of pelagic bacteria and heterotrophic nanoflagellates during the period May 5 to 25, used to calculate the average heterotrophic nanoflagellate clearance. $\mathrm{x}$ : concentration of bacteria; $\mathrm{y}$ : concentration of heterotrophic nanoflagellates. $\mathrm{dx} / \mathrm{dt}=0$ when the heterotrophic nanoflagellate population clearance $\left(F_{\text {pop }}\right)$ equals the bacterial growth rate. The clearance of an average heterotrophic nanoflagellate $(F)$ is calculated from $F=F_{p o p} / y$

populations depend on the eutrophic status of the system, i.e. the total amount of nutrients available for primary production. Fig. $7 \mathrm{~A}, \mathrm{~B}$ show the max. and min. concentrations of heterotrophic nanoflagellates and ciliates recorded from different marine environments differing in eutrophic status. Data from the Sargasso Sea (Caron 1983) and the Limfjord are provided as extreme examples of oligotrophic and eutrophic conditions. The stable population sizes observed during the winter, early spring and autumn can thus be explained by a low primary production and a low temperature. The low variability in the concentrations of heterotrophic nanoflagellates and ciliates in the oligotrophic areas, e.g. the Sargasso Sea (only flagellate data available) and parts of the Bering/Chukchi seas, indicates that here the populations of bacteria, heterotrophic nanoflagellates and ciliates are close to their carrying capacities $\left(x^{*}=K\right)$. Moreover, it indicates that the processes of production, grazing and mineralization approach a steady-state $(P \sim G \sim M)$. By contrast, the extreme variability in the concentrations found in the eutrophic areas, e.g. the Limfjord and Narragansett Bay, suggests that the mean concentrations are far removed from the carrying capacities of the popula- 
Fig. 7. Range of concentrations of heterotrophic nanoflagellates (A), and heterotrophic ciliates (B), from marine environments versus the 'eutrophic status' of the corresponding environments. Data from: (1) Caron (1983); (2) Andersen unpubl.; (3) Sherr \& Sherr (1984); (4) this investigation; (5) Beers \& Stewart (1971); (6) Sorokin (1977); (7) Capriulo \& Carpenter (1983); (8) Smetacek (1981)

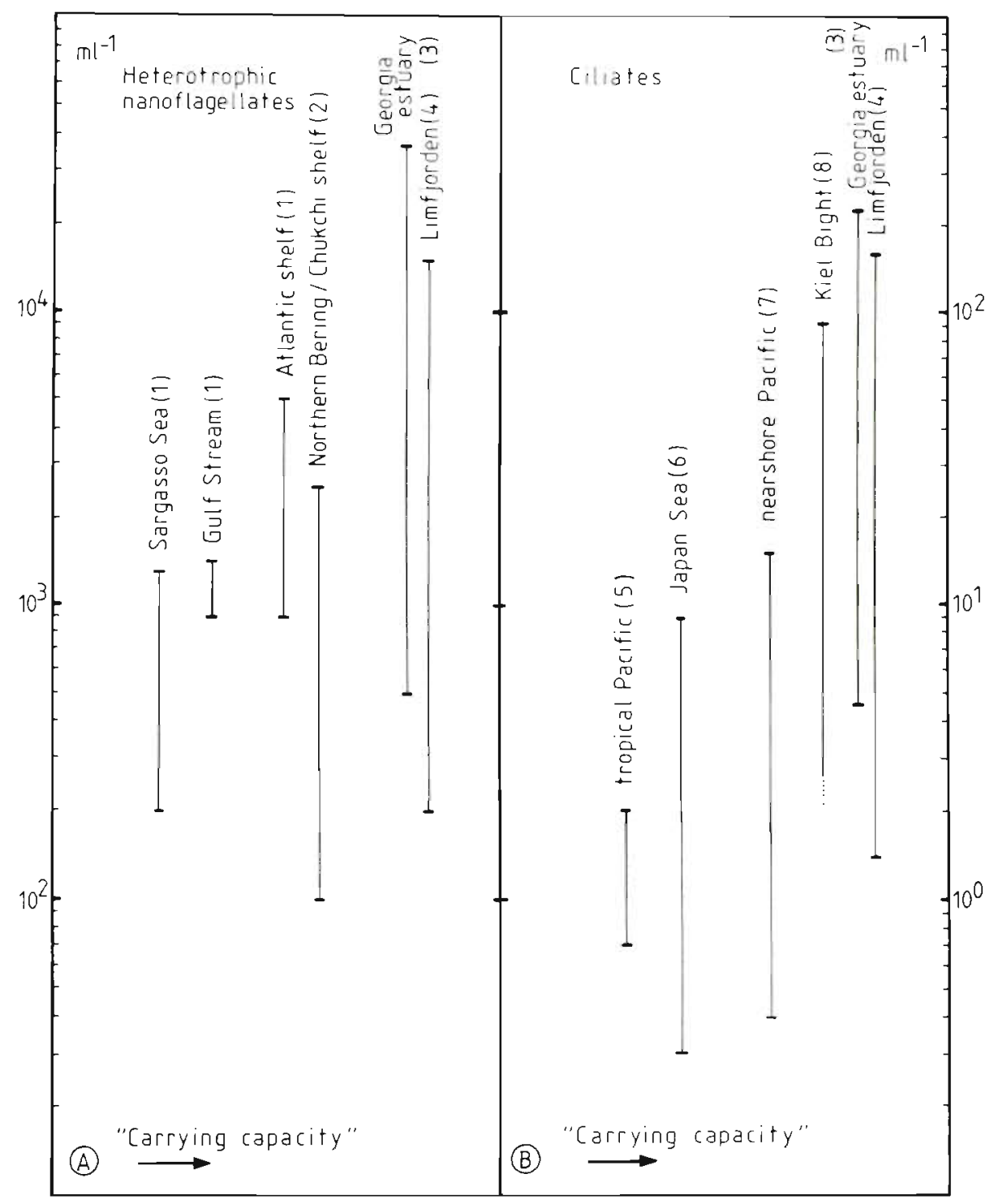

tions. This indicates that the processes of production, grazing and mineralization in these systems are out of balance most of the time.

The question raised by Ducklow (1983) concerning the development of bacterial blooms can be partially answered by the inherent oscillatory behavior of eutrophic prey-predator systems. In addition, the data presented here show that the inherent oscillatory behavior can be destabilized by the dynamic relation between the heterotrophic nanoflagellates and their grazers, in this case the ciliates, leading to extreme bacterial concentrations. Moreover, a sudden rise in the carrying capacity of the prey, e.g. due to the phytoplankton spring bloom or to hydrographic events, such as the inflow of nutrient-rich water experienced in June, will tend to destabilize the prey-predator oscillations, and initiate new successions of oscillations of bacteria, heterotrophic nanoflagellates and ciliates, as indicated by the present data, and previously reported by Sorokin (1977).

The observed heterotrophic nanoflagellate concentrations suggest that 5 to $365 \%$ (mean: $45 \%$ ) of the water-column was cleared for bacteria per day, assuming an average clearance of $2.4 \times 10^{-4} \mathrm{ml} \mathrm{d}^{-1}$ (Fenchel 1982b, Andersen \& Fenchel 1985). This estimate suggests that on average the bacterial growth rate should be around $0.5 \mathrm{~d}^{-1}$. This is close to the average of estimates from comparable environments (Williams 1984)

The ciliate population clearance, suggested from the observed ciliate concentrations and an assumed volume specific clearance of $10^{5} \mathrm{~h}^{-1}$ (Fenchel 1986b) was within the range of 4 to $352 \%$ per day (mean: $93 \%$ ). These rough estimates clearly represent the magnitude of the ciliates' importance as grazers on the nanoplankton in this environment. 
In general, our observations support what has been called the 'new paradigm' of the marine pelagic food web (Williams 1981) in which the pico-nano-microplankton constitutes an integrated component as important consumers, producers and mineralizers of organic material. The dynamic in situ population developments support the idea of a tight coupling between bacteria and heterotrophic nanoflagellates and between total nanoplankton and ciliates respectively.

Acknowledgements. We thank Prof. Tom Fenchel for valuable discussions during the research period and helpful critical comments on the manuscript. We are also grateful to $G$. $T$ Andersen and E. Christoffersen for assistance in collecting samples.

\section{LITERATURE CITED}

Andersen, P., Fenchel, T. (1985). Bacterivory by microheterotrophic flagellates in seawater samples. Limnol. Oceanogr. 30: 198-202

Anonymous (1976). Limfjordsundersøgelsen 1973-75. Delrapport 3. Institute of Water Quality, Copenhagen

Azam, F., Fenchel, T., Field, J. G., Meyer-Reil, L. A., Thingstad, F. (1983). The ecological role of water-column microbes in the sea. Mar. Ecol. Prog. Ser. 10: 257-263

Beers, J. R., Stewart, G. L. (1969). Micro-zooplankton and its abundance relative to larger zooplankton and seston components. Mar Biol. 4: 182-189

Beers, J. R., Stewart, G. L. (1971). Microzooplankters in the plankton communities of the upper waters of the eastern tropical Pacific. Deep Sea Res. 18: 861-883

Beers, J. R., Reid, F. M. H., Stewart, G. L. (1980). Microplankton population structure in Southern California nearshore waters in late spring. Mar. Biol. 60: 209-226

Capriulo, G. M., Carpenter, E. J. (1983). Abundance, species composition and feeding impact of tintinnid micro-zooplankton in central Long Island Sound. Mar. Ecol. Prog. Ser. 10: 277-288

Caron, D. A. (1983). Technique for enumeration of heterotrophic and phototrophic nanoplankton, using epifluorescence microscopy, and comparison with other procedures. Appl. environ. Microbiol. 46 (2): 491-498

Christiansen, F. B., Fenchel, T. (1977). Theories of populations in biological communities. Springer, Berlin

Davis, P. G., Sieburth, J. McN. (1982). Differentiation of phototrophic and heterotrophic nanoplankton populations in marine waters by epifluorescence microscopy. Ann. Inst. oceanogr., Paris. 58 (S) : 249-260

Davis, P. G., Sieburth, J. McN (1984). Estuarine and oceanic microflagellate predation of actively growing bacteria: estimation by frequency of dividing-divided bacteria. Mar. Ecol. Prog. Ser. 19: 237-246

Davis, P. G., Caron, D. A., Johnson, P. W., Sieburth, J. McN. (1985). Phototrophic and apochloric components of picoplankton and nanoplankton in the North Atlantic: geographical, vertical, seasonal and diel distributions. Mar. Ecol. Prog. Ser. 21. 15-26

Ducklow, H. W (1983). Production and fate of bacteria in the oceans. Bioscience $33(8): 494-501$

Fenchel, T. (1980). Relation between particle size selection and clearance in suspension feeding ciliates. Limnol. Oceanogr. 25: 733-738
Fenchel, T. (1982a). Ecology of heterotrophic microflagellates I. Some important forms and their functional morphology. Mar. Ecol. Prog. Ser. 8: 211-223

Fenchel, T. (1982b). Ecology of heterotrophic microflagellates II. Bioenergetics and growth. Mar. Ecol. Prog. Ser. 8: 225-231

Fenchel, T. (1982c). Ecology of heterotrophic microflagellates III. Adaptations to heterogeneous environments. Mar. Ecol. Prog. Ser. 9: 25-33

Fenchel, T. (1982d). Ecology of heterotrophic microflagellates IV. Quantitative occurrence and importance as bacterial consumers. Mar. Ecol. Prog. Ser. 9: 35-42

Fenchel, T. (1984). Suspended bacteria as a food source. In: Fasham, M. J. R. (ed.) Flows of energy and materials in marine ecosystems. Plenum Publ. Corp., New York, London, p. 301-315

Fenchel, T. (1986a). The ecology of heterotrophic microflagellates. In: Marshall, K. C. (ed.) Adv. Microb. Ecol. Vol. 9. Plenum Publ. Corp., New York, p. 57-97

Fenchel, T (1986b). Protozoan filter feeding. Prog. Protistology $1:$ in press

Ferguson, R. L., Rublee, P. (1976). Contribution of bacteria to standing crop of coastal plankton. Limnol. Oceanogr 21: $141-145$

Fuhrman, J. A., Azam, F. (1982). Thymidine incorporation as a measure of heterotrophic bacterioplankton production in marine surface waters: evaluation and field results. Mar. Biol. 66: 109-120

Haas, L. W., Webb, K. L. (1979). Nutritional mode of several non-pigmented micro-flagellates from the New York River Estuary, Virginia. J. exp. mar. Biol. Ecol. 39: 125-134

Heinbokel, J. F. (1978a). Studies on the functional role of tintinnids in the Southern California Bight. I. Grazing and growth rates in laboratory cultures. Mar. Biol. 47: 177-189

Heinbokel, J. F. (1978b). Studies on the functional role of tintinnids in the Southern California Bight. II. Grazing rates of field populations. Mar. Biol. 47: 191-197

Heinbokel, J. F., Beers, J. R. (1979). Studies on the functional role of tintinnids in the Southern Califormia Bight. III. Grazing impact on natural assemblages. Mar. Biol. 52: 23-32

Hobbie, J. E., Daley, R. J., Jasper, S. (1977). Use of Nucleopore filters for counting bacteria by fluorescence microscopy. Appl. environ. Microbiol. 33: 1225-1228

Johnson, P. W., Huai-Shu, X., Sieburth, J. McN. (1982). The utilization of chroococcoid cyanobacteria by marine protozooplankters but not by calanoid copepods. Ann. Inst océanogr., Paris 58 (S): 297-308

Laake, M., Dahle, A. B., Eberlein, K., Rein, K. (1983). A modeling approach to the interplay of carbohydrates, bacteria and non-pigmented flagellates in a controlled ecosystem experiment with Skeletonema costatum. Mar. Ecol. Prog. Ser. 14: 71-79

May, R. M. (1973). Stability and complexity in model ecosystems. Princeton Univ. Press, Princeton

Monstrup, Ø., Thomsen, H. A. (1982). Preparation of shadowcast whole mounts. In: Gantt, E. (ed.) Handbook of phycological methods. Vol. 3. Cambridge Univ. Press, Cambridge, New York, Melbourne, p. 385-390

Riemann, B., Nielsen, P., Jeppesen, M., Marcussen, B., Fuhrman, J. A. (1984). Diel changes in bacterial biomass and growth rates in coastal environments, determined by means of thymidine incorporation into DNA, frequency of dividing cells (FDC), and microautoradiography. Mar. Ecol. Prog. Ser. 17: 227-235

Sherr, B. F., Sherr, E. B. (1984). Role of heterotrophic protozoa 
in carbon and energy flow in aquatic ecosystems. In: Klug, M. J., Reddy, C. A. (ed.) Current perspectives in microbial ecology. American Society of Microbiology., Washington, D.C., p. $412-423$

Sherr, B. F., Sherr, E. B., Newell, S. Y. (1984). Abundance and productivity of heterotrophic nanoplankton in Georgia Coastal waters. J. Plankton Res. 6: 195-203

Smetacek, V (1981). The annual cycle of protozooplankton in the Kiel Bight. Mar. Biol. 63: 1-11

Sorokin, Y. I. (1977). The heterotrophic phase of plankton succession in the Japan Sea. Mar. Biol. 41: 107-117

Sorokin, Y. I. (1981). Microheterotrophic organisms in marine ecosystems. In: Longhurst, A. R. (ed.) Analysis of marine ecosystems. Academic Press, London, p. 293-342

Strathmann, R. R. (1967). Estimating the organic content of phytoplankton from cell volume or plasma volume. Limnol. Oceanogr. 12: 411-418
Verity, P. G. (1985). Grazing, respiration, excretion, and growth rates of tintinnids. Limnol. Oceanogr. $30(6)$ : 1268-1282

Verity, P. G. (1986a). Grazing of phototrophic nanoplankton by microzooplankton in Narragansett Bay. Mar. Ecol. Prog. Ser. 29: 105-115

Verity, P. G. (1986b). Growth rates of natural tintinnid populations in Narragansett Bay. Mar Ecol. Prog. Ser. 29: $117-126$

Williams, P. J. leB. (1981). Incorporation of the microheterotrophic processes into the classical paradigm of the planktonic food web. Kieler Meeresforsch. (Sonderh.) 5: 1-28

Williams, P. J. leB. (1984). Bacterial production in the marine food chain: the emperor's new suit of clothes? In: Fasham, M. J. R. (ed.) Flows of energy and materials in marine ecosystems. Plenum Publ. Corp., New York, London, p. 271-299

This article was presented by Professor T. Fenchel; it was accepted for printing on August 22, 1986 